\title{
Scientific Approach: Model-Based Inquiry in Teaching Narrative
}

\author{
Nurul Azizah Ria Kusrini \\ Institut Pesantren KH. Abdul Chalim \\ (Nurulazizah968@gmail.com)
}

\section{Key Words:}

Scientific approach

Model-Based inquiry

\section{ABSTRACT}

Curriculum 2013 is the latest curriculum created by the government to make the education in Indonesia better. Scientific approach offered in this curriculum is very remarkable to discuss, since almost all educators are talking about this approach. However, most of the educators get trouble and feel confused to apply this approach in teaching English, since it is usually applied in science class. Therefore, this study was written to show the steps of applying this approach in teaching English. This study, used library research, tried to offer new alternative vision to emerge the students' critical thinking through Model-Based Inquiry, an activity which is able to engage the student to learn more deeply with content and embody of five characteristic of scientific knowledge in which the idea presented in the form of models are testable, revisable, explanatory, conjectural and generative. This study provided the example of teaching narrative text which might be able to be applied in the various final products which could be alternative result of this strategy.

\section{ABSTRAK}

\section{Kata Kunci:}

Pendekatan saintifik

Model pembelajaran inquiry
Kurikulum 2013 merupakan kurikulum terbaru yang dikembangkan oleh pemerintah untuk meningkatkan kualitas pendidikan di indonesi. Hal yang menarik untuk dibahas dalam kurikukum ini yaitu pendekatan saintifik. Hampir seluruh pendidik di indonesia membahas pendekatan saintifik, namun banyak diantara mereka yang masih mengalami kesulitan dalam mengaplikasikan pendekatan tersebut dalam pengajaran bahasa Inggris. Oleh karena itu, jurnal ini disusun untuk menunjukkan bagaimana cara mengaplikasikan pendekatan saintifik dalam pengajaran bahasa Inggris. Melalui pendekatan kajian pusta, jurnal ini mencoba menawarkan visi alternatif baru untuk memunculkan pemikiran kritis siswa melalui Model Pembelajaran Inquiry suatu kegiatan yang mampu melibatkan siswa untuk belajar lebih dalam dengan konten dan mewujudkan lima karakteristik pengetahuan ilmiah dalam ide yang disajikan dalam bentuk model dapat diuji, direvisi, jelas, bersifat dugaan dan generatif. Jurnal ini memberikan contoh pengajaran teks naratif yang mungkin dapat diterapkan dalam berbagai produk akhir yang dapat menjadi hasil alternatif dari strategi ini. 


\section{Introduction}

Curriculum in Indonesia has been transformed for so many times to make education in Indonesia better than before. In fact, the condition of the education in this country is not significantly changed. The latest one, curriculum 2013, hopes to breakthrough the education in Indonesia. It offers new approach, scientific approach, which is hoped to make learning activities become more effective and relevant for students. Therefore, they can understand more and think critically to analyze and explore the material and to relate what they learnt to their daily life.

Commonly scientific approach is used to learn science and mostly used by students of science, not in English class. Gardner and Vygotsky declined this issue through their finding in Artemyeva (2005) that everyone has multi intelligent, such as verbal-linguistic, professional, musical, logical, and interpersonal self-knowledge. It means that everybody must have ability to think logically and analytically, hence, all they need is just practice.

The primary goal of scientific approach in education is to improve students' learning and to increase curious accessible to all students, including language learners. The essential of scientific approach in teaching learning is regarded appropriate to develop the students' behaviors, skills, and knowledge. In this approach the scientist had concerned more to inductive reason than deductive reason. It was done by observing specific object or situation to make conclusion generally which could be applied in wide area (Nasution).

\section{The Integration language, literacy and scientific approach}

In fact, Learning English at school is mainly aimed to help the students pass the national examination, since English is one of the subjects tested in this examination. So, the teachers mostly focus on the strategy which can ease the students to answer the questions based on the text. The teachers often put aside the students' comprehension about the text. Why is it so? Since the reading questions are in multiple choice forms, the teachers are easy to give the students strategy to find out the answers of those questions by searching the words in the text which are related to the questions, thus, the students do not need to comprehend the text to answer those questions. 
Scientific approach is a particularly powerful context for learning language and literacy (Stoddart). It means that by integrating subject matter with language and literacy development can enhance learning in two areas, passing the English proficiency level, and teaching high quality content. Therefore, through scientific approach it is hoped that the students are not only able to answer the questions for National Examination, but they also have skills to produce Language, written and oral, through their own experience in investigating and finding new things and through their critical thinking after combining the theory they read and their finding.

By relating language and literacy activities to the real life object, events, incident, and activities, the words they produce will have real meaning for the students. In scientific approach, the students can communicate their understanding in variety formats, such as story, diary, action, film project, graphic, role play and etc. The students are also able to describe, to explain, to justify, to argue, and to summarize hypothesis, which all of those activities are the steps in scientific approach (Stoddart). This approach can ease the students to learn, to reproduce, and to produce new text, such as description text, explanation text, and argumentative text.

\section{Model Based Inquiry}

Model-Based Inquiry is one of learning strategies in scientific approach. Model-Based Inquiry (MBI) is a kind of instructional strategy which can emerge the students' idea toward the model and construct their understanding of the model (Neilson et al.). What makes MBI acceptable and easier way to enhance the students' understanding is that the students create their own models rather than the teacher introduces a model for them. The students create the model based on their understanding, experience, and willingness. Then they use the model to share their knowledge and to determine what they do not understand yet about the concept. The next step, they will make observation to collect the data and then revise their model using new insight they have found.

In MBI, the students are asked to create their own model which can reflect their understanding of the concept. A model is a description which increases understanding of something that cannot be directly observed. The function of this model is as the anchor for 
learning to guide them to make the inquiry. Neilson et al (2010:39) offers the figure which reflects the Road map of Model-Based Inquiry.

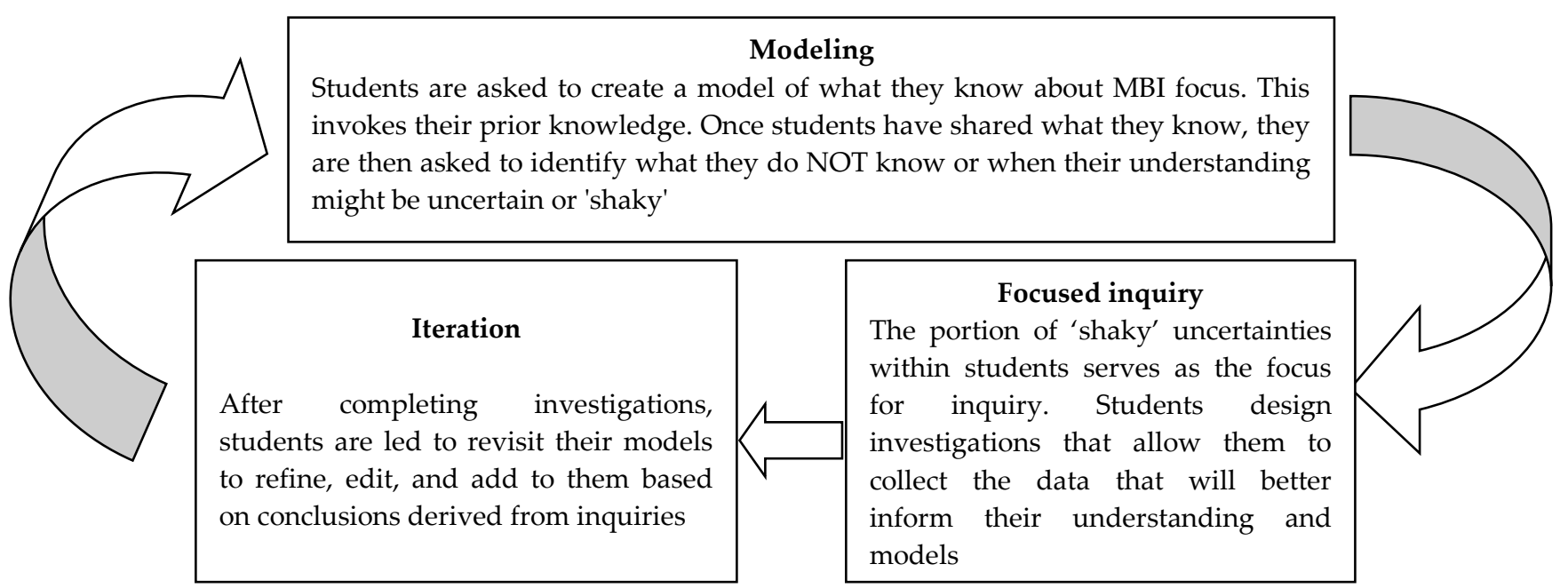

Figure 1. the map of Model-based Inquiry (Neilson et al.)

From the road map of MBI in Figure 1 above, the students may be engaged in three components of multidirectional cycle, modeling, focus inquiry and iteration. Firstly, in modeling step, each students starts observing the model to create outline or concept to demonstrate his or her understanding of the model. Secondly, in focused inquiry step, the students engage in the process of scientific approach which allow them to concept the inquiry, to collect the related information and to extract the explanation. The last, in iteration step, students connect emergent information or theory and explanation to their broader understanding and start to communicate it.

\section{Instructional Practice of inquiry process}

Based on the steps of scientific approach such as observing, questioning, experimenting, associating and communicating, inquiry process also has similar steps. There are 4 main phases of instructional practice of inquiry process, tunning in (preparation), guided for inquiry, independent inquiry, and culminating tasks (Alberta; Lane; Wilson and Murdoch).

The first phase is preparing the materials. The teacher selects the material which can provide 'thinking laverage' and must be appropriate with the curriculum (Wilson and Murdoch). The first phase also involves exploration or discovery tasks. The second phase is guided inquiry which involves careful examination of ideas discovered in the first phase, 
including varification of data and experimentation. The third phase extends the discussion outward from the text into the larger world. The activities in the last phase are organizing the result of data in phase two, then formulating an explanation, and the last is analyzing the data.

As an illustration of MBI in English class, this article will povide the example of one of text genres, narrative text because this text is discussed in both junior high school and senior high school. this text has many various, start from legend, tales, to real story. The narrative text used must be different for each level. It will be better if the teacher selects different kinds of narrative text to use in the class.

\section{Phase one}

In the first phase the students are divided into some groups and each group will be given different text, for instance group 1 is given text about legend, group 2 will get fairytale, etc. the teacher doesn't give the real text, but only the kinds of narrative text. First,each groups will decide the title of the text they want to choose. Then, they will find pictures (picture series will be better) related to the text chosen to be their model. The next step is they try to make questions based on the pictures.

For another option, teacher may give the students the topic or the theme of the text for their project. To make it more challanging, they must create story which is different with the real version. This can force the students to pull out their ideas, imagination, and creativity. For example, teacher may give them topic, like tiger and rabbit for fable, the craziest thing you have done for real story, and etc. Teacher may provide different topics for each group or one topic for all groups. By taking the first option, it can give the students opportunity to share and to learn different knowledge and to have more opportunity to find the best title for their text. Giving one topic for all groups can dare the groups more because they will find difficulties to find the best title for their text since it should not be the same for each group.

For senior high school students, I think it will not be difficult for them to make yes/no questions and WH-questions, such as Who are involved in the story?where were they? Was she happy? etc. However, junior high school students may find difficulties to make such questions, thus the teacher should train them first. One of the ways to do that is by giving game, question game. This game needs two dices labeled with words that can be combined to form the question 
terms. One dice features the words 'what', 'who', 'where/when', 'which', 'how' and 'why'. Another dices features the auxilary verbs 'is (was)', does (did)', 'would', 'might', 'will', and 'can (could)'. When the two dice are rolled together, the two words uppermost on the dice must be combined to form the stem of a question. It will be better if the students try to make question related to the picture they choose.

As variation, each group should write the questions based on the rolling dice on a piace of paper. The questions made in the first phase are still about what they see from the picture (Murdoch). Then they display it on the wall of the classroom and students walk around to look at the questions. They should also stick on the pictures on the wall above the questions sheet. Each group should bring a black marker while walking around the class and looking at the questions. They will draw small dot next to the question they interest most or they think as the closest to the picture. The teacher also gives mark by drawing red dot on the best question each group has made. Then the questions dotted, black and red can be incorporated into planning in the next phase after they answer them.

\section{Phase two}

Phase two is about data gathering through verification and experimentation. It is also important concept to examine the text separately (Babin). From that satetement, it can be seen that in this phase the students should be able to separete text, setting, problem, solution, and the end of the story. from the result questions they have made in the first phase, they classify them to the classification above. And of course that data is not sufficient yet to make complete text. They have to dig more information by creating questions which are deeper and suitable with their need to complete the text.

The questions are answered by the students themselves, but they may ask the questions to their friends, teachers, parents, and other people who they think they have knowledge about the story. By asking to different people, they may have various answers about a story. it will challenge them to decide how they will examine the answers, by combining those answers to make different plot of story or picking and choosing the answers which are suitable with their ideas about the story. After that they start working in group to complete the text with their own 
version. A different opinion in the group may happen, thus, the teacher should be able to give great solution for them, for instance by asking them to vote the best idea, or giving them chance to create their own versions.

After they complete the text, it is a time for them to make experiment about their text. Each group should present the story in their versions and also prepare some questions to get the oponion of the readers. The question may be such, what do you think about the story? is it easy to understand? is the story interesting or boring?why?is the story organized well?has the story met the structure of narrative?, etc. From the respond of those questions, the students can revise the story and examine it deeper, to make it more interesting not only for them but for the readers, in the next phase.

\section{Phase Three}

The final phase of the discussion leads the students to create other meaning and to judge the degree to which the text at hand matches its potential purpose (Windschitl et al.; Zwickle and Noah Finkelstein). In this phase the students start to decide first the best version of the story in the group based on the input they have got from others - friends, teachers, and other audiences and readers, and then they should revise it. Next, they should search and collect the theory about narrative, such as about the structure, the grammar features, etc. The students will analyze the story they have made based on the theory they read. Next, they can explain the purpose of the story, the structures, the grammar feature, and the moral view of the story.

After they did all those steps, it's time for them to present the story they have made and explain to prove that the story they have made is narrative text. The other groups will give them questions about their explanation. Discussion will happen in this phase. The teacher has a role as facilitator and also as mediator to help this discussion succeeds. After all groups have presented their story and analysis, they have to make the conclusion about the characteristics of narrative since they have got different kinds of narrative.

For final project, there are many various of final project which can be alternative for teachers. First and the simplest one, the teacher asks the students to collect all stories and the analysis from all groups and make it into book. And of course the big challenge for them is to make the cover of the collection story. The purpose of this project is to sharpen the creativity and 
the imagination of the students. The next option is by creating movie. Each groups will make the story they have made into movie. This is a bit difficult because the students should be able to change their story to be a scenario (dialogue), to direct their friends, to act, and to express well . To make it more challenging, the movie they make can be uploaded into internet, and the group who have the most viewer will have the best score. And many other thing which can be done by teacher to challenge their students to be more active and creative.

\section{Conclusion}

Model-based inquiry is created based on the method of inquiry-based learning which can be used to actively engage students in a deep exploration of the concepts and skills associated with the lesson. The construction and order of the questions are important consideration for learning because by giving thoughtful attention to the needs of students and to principles of critical thinking, teachers can ensure that the direction of the discussion is productive. To be careful in ordering the questions will help students build their understanding effectively.

This method also can give more benefits for the students in learning process because it allows the students to make their own decision about what they learn and responsible with it and teacher just makes sure that they have necessary knowledge, skill and strategies to expand their abilities by attempting challenging task. Another benefit is able to build on students' natural curiosity and lead to the development of higher-order thinking skills (Murdoch).

\section{Bibliography}

Alberta. Focus on Inquiry: A Teacher's Guide to Implementing Inquiry Based Learning. Alberta Learning, 2004.

Babin, Cheryl. "Getting Started with Students Inquiry." Capacity Building Series, 24th ed., Ontario Ministry of Education, 2011.

Lane, J. .. Inquiry Based Learning. University Press., 2007.

Murdoch, K. Take a Moment: 40 Frameworks for Reflective Thinking. Seastar Education, 2005.

Neilson, D., et al. "Model-Based Inquiry in Physics: A Buoyant Force Module." Utah State 
University, vol. 77, no. 8, 2010, pp. 38-43.

Stoddart, Trish. Effective Science Teaching for English Language Learners (ESTELL) Measuring Pre Service Teacher Practice. American Educational Research Association, 2011.

Wilson, J., and K. Murdoch. How to Succeed with Thinking. Curriculum Coorperation Melbourne, 2006.

Windschitl, Mark, et al. Beyod the Scientific Method: Model-Based Inquiry as a New Paradigm of Preference for School Science Investigation. Wiley Inter Science Inc, 2007.

Zwickle, Benjamin M., and H. J.Lewandowski Noah Finkelstein. A Framework for Incorporating Model-Based Inquiry into Physics Laboratory Courses. University of Colorado, 2013.

Nurul Azizah Ria Kusrini

Scientific Approach: Model-Based Inquiry in

ALSUNA Vol. 1 (1), 2018

Teaching Narrative 